\title{
異文化受容態度と友人関係
}

泉水清志 小池庸生

育英短期大学 現代コミュニケーション学科)

キーワード 異文化受容態度、友人関係

Receptive Attitudes toward Different Cultures and Friendship

KIYOSHI SENSUI · NOBUO KOIKE

(KUEI J unior College)

Key words receptive attitudes toward different cultures ,friendship

目的

異文化との接触は、異文化に対する好意的な感青や積極的な関与 を促進することか明らかとされており、特に異文化友人との接触がコ ミュニケーシシやや意識的配慮を活性化し、社会的アイデンテ价け 認知を促進させるため、積極的な関与への動機つけを高めることが 指摘されている泉水 小池,2012)。また 異文化との接触は光のコミ ユニケーシシににおいて 笑いが重要であると認識し 弚れを友人関 係にも生か弚うとしていることも示唆されている泉水 小池,2011)。

以上のことから，異文化接触によって影響される異文化受容態度と 友人関係にも関連性があることか推測される。本研究ては、異文化受 容態度の高さと友人関係、乥の重機つけやや満足感の関連性について 検討することを目的とした。

方法

調查対象者 大学生 短期大学生 346名 男子 42名、女子 304名、平 均年齢 18.9 歳)

調査内容 頊目 以下について 5件法て回答を求めた。

1) 自国と外国への態度尺度 向井ら,2003)25項目

2) 友人関係尺度 岡田, 1999)17項目

3）友人関係への重機づナ尺度 岡田，2005)16項目

4) 友人満足感尺度 加藤, 2001)6項目

また、異文化接触 親族の移民経験、外国籍の友人 同クラス経験 近 隣在住)の有無についても尋ねた。

\section{結果 考察}

異文化受容態度について、自国と外国への態度尺度結果 $M=$ $3.56, \mathrm{SD}=0.39$ )をG-P分析によって高群 NE 3.82、88名) と低群 NES 3.30、86名)に分けて検討した。

友人関係

表 1 は、異文化受容態度の高低群ごとに5つの因子の結果を まとめたものである。2 群) $\times 5$ 因子)の分散分析を行つた結果、 群 $F$ 1,860) $=47.65, p<.001$ ) と因子の主効果 $F 4,860)=32.06$, $p<.001$ )、また群と因子の交互作用 $F \quad 4,800)=3.00, p<.05)$ に おいて有意差がみられた。表 1 よ以友人関係ては 気遣いや 笑いを重視することが分かり，異文化受容態度か高まると他者 への意諳的配慮力高まるため、友人関係、特に気遣いへの意 識か高まることが考えられた。

友人関係への満足感

表2は、異文化受容態度の高低群ごとにと4つの因子の結果を まとめたものである。2 群) $\times 4$ 因子)の分散分析を行つた結果、 群 $F$ 1,688) $=110.44, p<.001)$ と因子の主効果 $F \quad 4,688)=$ $215.55, p<.001$ )において有意差がみられた。表2より，友人関係 への動機つけは 内的」同一化」取り入れ」外的」の順に高いこ
とが分かり、異文化受容態度か高まると友人関係への意識が高 まるために穴の動機つけも高まることが考えられた。

友人関係への満足感

表3は、異文化受容態度の高低群ごとに6項目の結果をまとめ たものである。2 群) $\times 6$ 項目)の分散分析を行つ十結果、群 $F$ $1,1032)=56.32, p<.001)$ と因子の主効果 $F \quad 4,1032)=70.74, p$ <.01)において有意差がみられた。表 3 よ以、友人関係への満足 感は 親友の存在や友人からの理解」ては高いが 友人全員か らの好意」ては低いことが分かり，異文化受容態度が高まると友

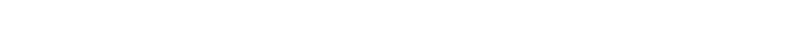
ことが考えられた。

表 1 異文化受容態度と友人関係

\begin{tabular}{|c|c|c|c|c|c|c|c|}
\hline \multirow{2}{*}{} & \multicolumn{7}{|c|}{ 因子 } \\
\cline { 2 - 9 } & \multicolumn{2}{|c|}{ 群れ } & 他者配慮 & 笑い & $\begin{array}{c}\text { プライ } \\
\text { バシー }\end{array}$ & 気遣い & 計 \\
\hline $\begin{array}{c}\text { 異文化受容 } \\
\text { 態度低群 }\end{array}$ & 平均値 & 3.33 & 3.17 & 3.63 & 3.31 & 3.72 & 3.43 \\
\hline 異文化受容 & 平均値 & 3.66 & 3.50 & 3.99 & 3.35 & 4.28 & 3.76 \\
\hline 態度高群 & $(\mathrm{SD})$ & $(0.58)$ & $(0.55)$ & $(0.90)$ & $(0.84)$ & $(0.63)$ & $(0.76)$ \\
\hline
\end{tabular}

表 2 異文化受容態度と友人関係への動機つけ

\begin{tabular}{|c|c|c|c|c|c|c|}
\hline \multicolumn{2}{|c|}{} & \multicolumn{5}{|c|}{ 因子 } \\
\cline { 3 - 8 } \multicolumn{2}{|c|}{} & 外的 & 取り入れ & 同一化 & 内的 & 計 \\
\hline 異文化受容 & 平均値 & 2.73 & 3.45 & 3.99 & 4.33 & 3.63 \\
態度低群 & (SD) & $(0.55)$ & $(0.73)$ & $(0.72)$ & $(0.66)$ & $(0.90)$ \\
\hline 異文化受容 & 平均值 & 3.13 & 4.08 & 4.6 & 4.75 & 4.14 \\
態度群 & (SD) & $(0.77)$ & $(0.70)$ & $(0.48)$ & $(0.42)$ & $(0.88)$ \\
\hline
\end{tabular}

表 3 異文化受容態度と友人関係への満足感

\begin{tabular}{|c|c|c|c|c|c|c|c|c|}
\hline \multicolumn{2}{|c|}{} & $\begin{array}{c}\text { 友人から } \\
\text { の受容 }\end{array}$ & $\begin{array}{c}\text { 気持5の } \\
\text { 通じい }\end{array}$ & $\begin{array}{c}\text { 友人から } \\
\text { の理解 }\end{array}$ & $\begin{array}{c}\text { 親友の } \\
\text { 存在 }\end{array}$ & $\begin{array}{c}\text { 友人全員 } \\
\text { からの好意 }\end{array}$ & $\begin{array}{c}\text { 友人から } \\
\text { の支持 }\end{array}$ & 計 \\
\hline $\begin{array}{c}\text { 異文化受容 } \\
\text { 態度低群 }\end{array}$ & $\begin{array}{c}\text { 平均值 } \\
(S D)\end{array}$ & 3.52 & 3.48 & 4.01 & 4.11 & 2.65 & 3.34 & 3.52 \\
\hline $\begin{array}{c}\text { 異文化受容 } \\
\text { 態度高群 }\end{array}$ & $\begin{array}{c}\text { 平均值 } \\
(\mathrm{SD})\end{array}$ & $3.71)$ & $(0.68)$ & $(0.97)$ & $(1.08)$ & $(0.71)$ & $(0.74)$ & $(0.95)$ \\
\hline
\end{tabular}

\section{引用文献}

泉水清志 小池庸生 2011). 異文化接触と友人関係 日本心理学会 第 75 回大会論文集

泉水清志 小池庸生 2012). 異文化接触潩文化受容態度と友人関 係に及ぼす影響 育英短期大学研究紀要, 25-42

* 本研究は、平成 22 年度文部科学省科学研究費補助金 基盤研 究 B)課題番号 22320177 現代日本の青年層の異文化観に関 する研究 - 群馬県における高校生 大学生の意識の分析 - 」 研究代表者 小野澤正喜)を受けて行われた研究データの一 部を使用した。 